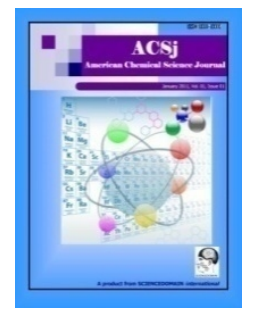

American Chemical Science Journal

2(2): 60-68, 2012

SCIENCEDOMAIN international

www.sciencedomain.org

\title{
Microbial Decolourization of an Anthraquinone Dye C.I. Reactive Blue 19 Using Bacillus cereus
}

\author{
Abdulraheem Giwa ${ }^{{ }^{*}}$, Fatima J. Giwa ${ }^{2}$ and Bamidi J. Ifu ${ }^{1}$ \\ ${ }^{1}$ Department of Textile Science and Technology, Ahmadu Bello University, Zaria, Nigeria. \\ ${ }^{2}$ Department of Medical Microbiology, Ahmadu Bello University, Zaria, Nigeria.
}

Authors' contributions

This work was carried out in collaboration between all authors. AG and FJG designed the study, performed the statistical analysis, wrote the protocol, and wrote the first draft of the manuscript. BJI managed the analyses of the study. AG managed the literature searches.

All authors read and approved the final manuscript.

Research Article

Received $28^{\text {th }}$ April 2012

Accepted $9^{\text {th }}$ July 2012

Online Ready $20^{\text {th }}$ July 2012

\section{ABSTRACT}

Aims: This work aimed at using $B$. cereus strain to decolourize a textile dye and also to study the influence of various environmental parameters on the decolourization processes. Study Design: Decolourization efficiency of $B$. cereus.

Place and Duration of Study: Department of Microbiology, Ahmadu Bello University, Zaria, Nigeria; Department of Medical Microbiology, Faculty of Medicine, Ahmadu Bello University, Zaria, Nigeria and Department of Textile Science and Technology, Ahmadu Bello University, Zaria, Nigeria, between March 2011 and September 2011.

Methodology: The $B$. cereus strain used was isolated from contaminated food by using a selective media (Mannitol egg yolk polymyxin agar) and then culturing and storing on nutrient agar slants at $-20^{\circ} \mathrm{C}$ after biochemical tests were done to identify the isolate. All the microbial batch experiments were carried out at ambient conditions in $250 \mathrm{ml}$ Erlenmeyer flasks. Nutrient broth was autoclaved at $121^{\circ} \mathrm{C}$ at $15 \mathrm{psi}$ for $15 \mathrm{~min}$ and nutrient agar plates were also used in the isolation of the $B$. cereus strain. Effects of various parameters, including initial dye concentration $(0,0.5,1.0$ and $2.0 \mathrm{~g} / \mathrm{l})$, glucose concentration (50,100, 200 and $500 \mathrm{mg} / \mathrm{l}), \mathrm{pH}(4.0,7.0$ and 10.0) and temperature $(20,27$ and $40^{\circ} \mathrm{C}$ ), on dye decolourization were investigated. Decolourization extent was determined by measuring the absorbance of the culture supernatant at $591 \mathrm{~nm}$ using a Unicam UV9100-visible spectrophotometer. Decolourization extent was calculated using a 
standard equation as specified by Giwa et al., 2011.

Results: The bacteria culture exhibited $95 \%$ decolourization ability within 72 hours. The optimum dye decolourizing activity of the culture was observed at $\mathrm{pH} 7.0$ and incubation temperature of $27^{\circ} \mathrm{C}$. Maximum dye decolourizing efficiency was observed at $200 \mathrm{mg} / \mathrm{l}$ concentration of RB19. The dye solution showed high peak at the wavelength of $591 \mathrm{~nm}$.

Conclusion: The results thus obtained have characterized and identified the dye degrading ability of the $B$. cereus. The presence of a co-substrate (glucose) is an essential condition for attaining maximum decolourization efficiency. Reactive blue 19 was completely and rapidly decolourized by $B$. cereus after 3days of incubation with different effects on the dye as seen in the result.

Keywords: Microbial oxidation; anthraquinone dye; C.I. reactive blue 19; decolourization; $B$. cereus.

\section{INTRODUCTION}

Synthetic dyes are widely used in the textile, cosmetic, printing, drug and food processing industries (Padamavathy et al., 2003). The generation of coloured wastewaters is a problematic reality for a variety of industrial sectors. Among these are effluents released from textile and printing processes, dry cleaning and tanneries, the food industries, manufacture of paints and varnishes, manufacture of plastics and a variety of chemical processes.

Insufficient treatment of wastes of the dyestuff industries leads to dye contamination of the environment such as soil and natural water bodies (Pearce et al., 2003). Commercial dyes have variety of colours and a high stability to light, temperature and microbial attack. Not only is the colour aesthetically unacceptable, it also affects aquatic ecosystem by decreasing the light penetration and solubility of gases (Saranaik and Kanekar, 1995). Furthermore, some synthetic dyes such as azo dyes are carcinogenic or mutagenic (Spadaro et al., 1992). Physico-chemical treatment processes have disadvantages in that the contaminant is not destroyed, it is simply concentrated and subsequently deposited in landfills or incinerated, while biological treatment methods are cheap and offer the best alternative with proper analysis and environmental control (Banat et al., 1996).

One promising strategy is the use of microbes that possess the ability to decolourize synthetic dyes including white rot fungal and bacterial strains (Liu et al., 2004; Hadibarata et al., 2012a, 2012b). Microbial decolourization and degradation is an environmentally friendly and cost-competitive alternative to physico-chemical decomposition processes for the treatment of industrial effluents (Verma and Madamwar, 2003).

Many bacterial, fungal and algal species have the ability to absorb and/or degrade textile dyes. Bacteria decolourization of azo dyes is either aerobic or anaerobic (Forgacs et al., 2004; Pandey et al., 2007). Nature is full of bacterial diversity. Azo dye decolourizing bacteria can be isolated from soil, water, human and animal excreta and even from contaminated food materials. However, other potential ecological niches for isolating such bacteria are coloured effluents arising from dye manufacturing and textile industries. 
This work aimed at using $B$. cereus strain to decolourize a textile dye and also to study the influence of various environmental parameters on the decolourization processes.

\section{MATERIALS AND METHODS}

\subsection{Microbial Oxidation System of Decolourizing Bacteria}

The $B$. cereus strain used was isolated from contaminated food by using a selective media (Mannitol egg yolk polymyxin agar) and then culturing and storing on nutrient agar slants at $20^{\circ} \mathrm{C}$ after biochemical tests were done to identify the isolate in the department of Microbiology, Ahmadu Bello University, Zaria, Nigeria. All the microbial batch experiments were carried out at ambient conditions in $250 \mathrm{ml}$ Erlenmeyer flasks. Nutrient broth $(100 \mathrm{ml}$ of distilled water containing peptone $0.5 \mathrm{~g}$, yeast extract $0.3 \mathrm{~g}$, beef extract $0.2 \mathrm{~g}$, sodium chloride $0.5 \mathrm{~g}$ ) was autoclaved at $121^{\circ} \mathrm{C}$ at $15 \mathrm{psi}$ for $15 \mathrm{~min}$ and nutrient agar plates were also used in the isolation of the $B$. cereus strain.

Colonies of $B$. cereus growing on nutrient agar slants were inoculated into sterile $10 \mathrm{ml}$ nutrient broth in universal bottles to make the bacterial suspension. This was cultured on sterile nutrient agar plates and incubated at 37 for 24 hours to obtain discrete colonies. After the period of incubation, characteristically large creamy colonies growing on nutrient agar plates were identified by morphological, cultural and biochemical tests following the current method recommended in the US Food and Drugs Administration Bacteriological Analytical Manual (BAM 2) (Rhodehamel et al., 2001)

\subsection{Effects of Different Parameters on Dye Decolourization}

The bacteria was cultured in LB medium at $150 \mathrm{rpm}, 37^{\circ} \mathrm{C}$ for $12 \mathrm{hours}$ before the bacterial cells were collected by centrifugation ( $5000 \mathrm{rpm}$ for $5 \mathrm{~min}$ ) and re-suspended in modified M9 synthetic medium. The bacterial suspension was inoculated in $100 \mathrm{ml}$ Erlenmeyer flasks containing $60 \mathrm{ml}$ modified M9 medium to study the effect of the conditions at 150rpm and $37^{\circ} \mathrm{C}$. Effects of various parameters, including initial dye concentration $(0,0.5,1$ and $2 \mathrm{~g} / \mathrm{l})$, glucose concentration (50,100, 200 and $500 \mathrm{mg} / \mathrm{l}), \mathrm{pH}(4.0,7.0$ and 10.0) and temperature $\left(20,27\right.$ and $\left.40^{\circ} \mathrm{C}\right)$, on dye decolourization were investigated. Experiments were performed in a $15 \mathrm{ml}$ glass tubes containing $10 \mathrm{ml}$ of the medium. The bacterial cell suspension was inoculated into the tubes and the optical density $(600 \mathrm{~nm})$ was 0.3 . Each experiment was carried out in triplicate, and the average was recorded.

\subsection{Bacteria Decolorization of Reactive Blue 19}

The bacterial cell suspension was autoclaved at $121^{\circ} \mathrm{C}$ at $15 \mathrm{psi}$ for half an hour and then added into the medium and the decolourization extent tested. Bacterial cells without treatment were added into the medium as a control. Both the experiments of decolourization by treated and untreated bacterial cells were performed under anaerobic conditions. After incubation for 48hours, samples from the control culture were centrifuged at 5000rpm for $5 \mathrm{~min}$ and the supernatant was scanned from 300-700nm using a Unicam UV9100-visible spectrophotometer to detect any transformation of compounds in the medium. 


\subsection{Measurement of Decolourization Extent}

Samples $(0.4 \mathrm{ml})$ were collected every 24 hours and centrifuged at 5000rpm for $5 \mathrm{~min}$. Decolourization extent was determined by measuring the absorbance of the culture supernatant at $591 \mathrm{~nm}$ using a Unicam UV9100-visible spectrophotometer. Decolourization extent was calculated using the following equation 1 (Giwa et al., 2011):

$$
\text { Decolorization extent }(\%)=\frac{C_{o}-C_{t}}{C_{o}} \times 100 \quad \text { Equation } 1
$$

Where $C_{o}$ refers to the initial absorbance, $C_{t}$ refers to the absorbance after incubation; and $t$ refers to the incubation time.

\subsection{Statistical Analysis}

The knowledge that any individual measurement that is made in the laboratory may lack perfect precision has led us to choose to take multiple measurements of decolourization efficiency. Though no one of these measurements are likely to be more precise than any other, this group of values, it is hoped, will cluster about the true value we are trying to measure. The distribution of data values is represented by showing a single data point, representing the mean value of the data and error bars to represent the overall distribution of the data. These error bars are graphical representation of the variability of our data and are used on respective graphs to indicate the error, or uncertainty in our reported decolourization efficiency measurement. Error bars give a general idea of how accurate a measurement is, or conversely, how far from the reported value the true (error free) value might be. However, here in our report, error bars represent $95 \%$ confidence interval. It is worthy to mention that instead of creating a graph using all of the raw data, now only the mean value is plotted with error bars for percentage decolourization.

\section{RESULTS AND DISCUSSION}

The properties of the dye used are shown in Table 1.

\subsection{Effect of Dye Concentration of RB19}

Decolourization activity of the bacterial culture of $B$. cereus was studied using Reactive blue 19 at different concentrations varying from $0.0 \mathrm{~g} / \mathrm{l}$ to $2.0 \mathrm{~g} / \mathrm{l}$ (Fig. 1). Rate of decolourization increased with increase in initial dye concentration up to $1.0 \mathrm{~g} / \mathrm{l}(97.89 \%$ decolourization). Further increase in dye concentration resulted in reduction in decolourization rates. A survey of the literature suggests that increasing the dye concentration gradually decreases the decolourization rate, probably due to the toxic effect of dyes with regard to the individual bacteria and/or inadequate biomass concentration (or improper cell to dye ratio), as well as blockage of active sites of azoreductase by dye molecules with different structures (Jadhav et al., 2008; Saratale et al., 2009a).

Similar results were observed in the bacterial decolourization of various reactive azo dyes (Saratale et al., 2009b). It was also observed that reactive group azo dyes with sulfonic acid $\left(\mathrm{SO}_{3} \mathrm{H}\right)$ groups on their aromatic rings greatly inhibited the growth of microorganisms at higher dye concentrations (Kalyani et al., 2008). 
Table 1. Properties of RB19

\begin{tabular}{|c|c|}
\hline Property & Dye \\
\hline C. I. Name & Reactive Blue 19 \\
\hline Commercial Name & Remazol Brilliant Blue R \\
\hline Functional group & Anthraquinone \\
\hline CAS Number & $2580-78-1$ \\
\hline C.I. Number & 61200 \\
\hline Mol. Mass $(\mathrm{g} / \mathrm{mol})$ & 626.54 \\
\hline Mol. Formula & $\mathrm{C}_{22} \mathrm{H}_{16} \mathrm{~N}$ \\
\hline \multicolumn{2}{|l|}{ Chemical Formula } \\
\hline Lambda max (nm) & 591 \\
\hline Purity (\%) & 99 \\
\hline Solubility & 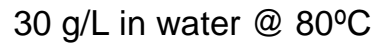 \\
\hline Manufacturer & SIGMA \\
\hline $\mathrm{pH}$ of stock solution & $6.524 @ 31.3^{\circ} \mathrm{C}$ \\
\hline
\end{tabular}

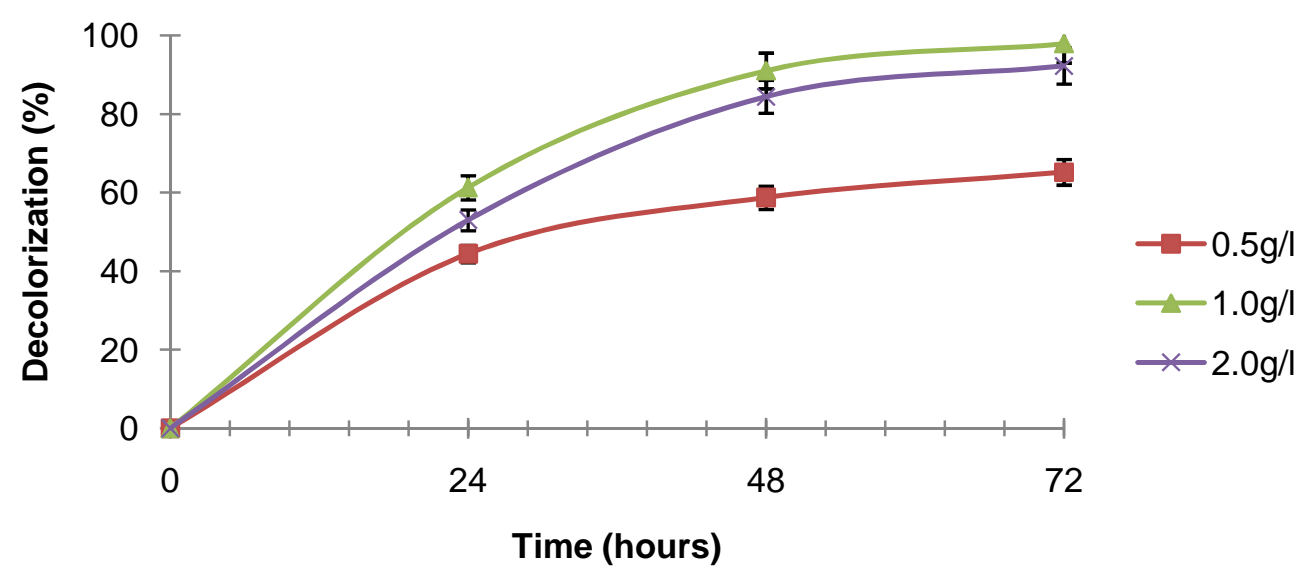

Fig. 1. Dye Concentration Curve for RB19 and each data point is the average of triplicates and the error bars represent $95 \%$ confidence interval

\subsection{Effect of Glucose Concentration on Decolourization of RB19}

The decolourization efficiencies were almost the same as the concentration of glucose was increased from 50 to $200 \mathrm{mg} / \mathrm{l}$ (Fig. 2). The colour removal efficiencies reached a peak resulting in a decolourization efficiency of $99 \%$ after 3 days of incubation period. However, $50 \%$ decolourization removal was obtained for concentration of $500 \mathrm{mg} / \mathrm{l}$ after 3days of incubation. In this study, our strain required sugar especially, glucose for decolourization. This result seems to suggest that the decolourization activity of this strain might be a sugar 
oxidase as the same with Coriol us sp. No.20 (Watanabe et al., 1982) and C. versi colour Ps4a (Ohmomo et al., 1988).

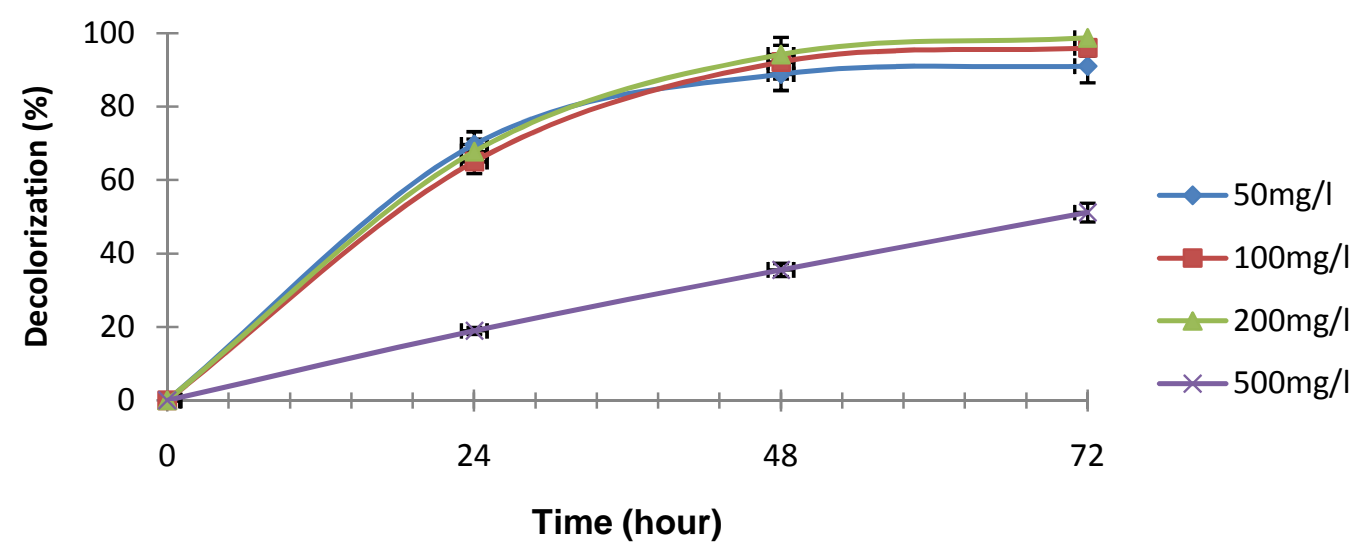

Fig. 2. Glucose Concentration Curve for RB19 and each data point is the average of triplicates and the error bars represent $95 \%$ confidence interval

\subsection{Effect of pH on Decolourization of RB19}

Bacterial culture generally exhibits maximum decolourization rate at $\mathrm{pH}$ values near 7 . Decolourization of C.I. Reactive Blue 19 at various $\mathrm{pH}$ values by $B$. cereus was studied. Fig. 3 shows that an increase in $\mathrm{pH}$ from 4.0 to 7.0 gives $19.98 \%$ and $95.99 \%$ decolourization respectively, while decolourization rate decreased as $\mathrm{pH}$ was increased from 7.0 to 10.0, a concomitant reduction in decolourization from $95.99 \%$ to $76.67 \%$ was observed. The rate of decolourization for $B$. cereus was optimum in this narrow $\mathrm{pH}$ range.

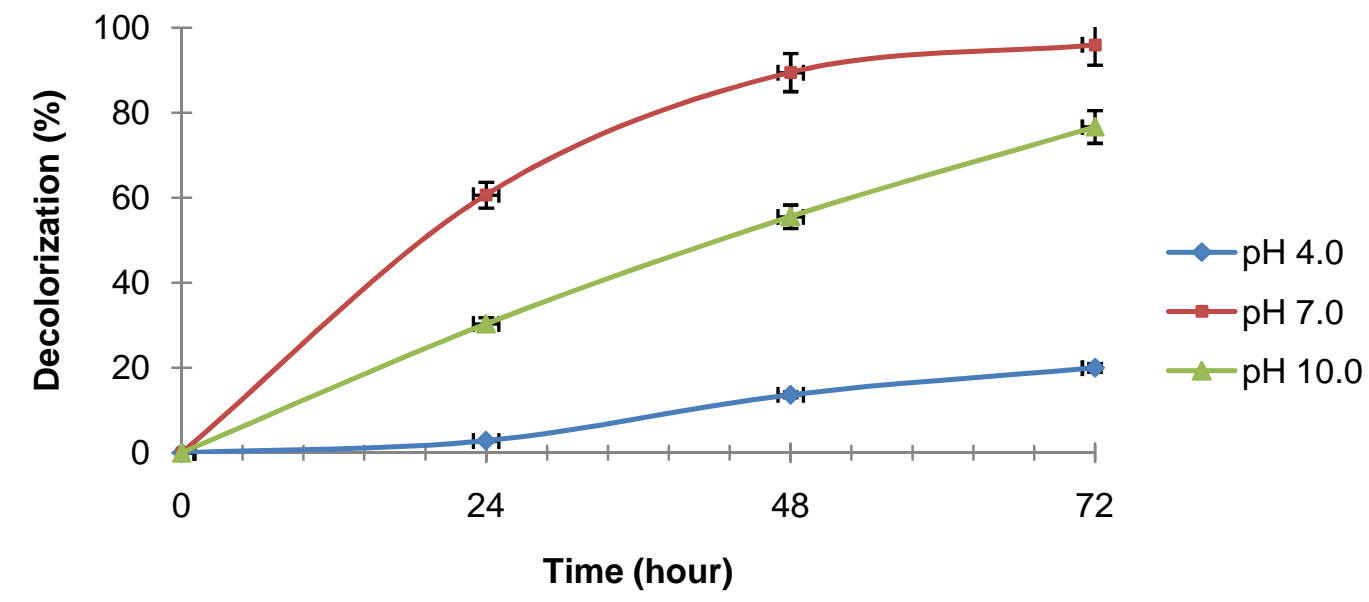

Fig. 3. pH Curve of decolourization of RB19 and each data point is the average of triplicates and the error bars represent $95 \%$ confidence interval

These results show that the $\mathrm{pH}$ of the medium is also an important factor with regards to decolourization. The rate of colour removal is higher at the optimum $\mathrm{pH}$, and tends to 
decrease rapidly at strongly acid or strongly alkaline $\mathrm{pH}$. It is thought that the effect of $\mathrm{pH}$ may be related to the transport of dye molecules across the cell membrane, which is considered as the rate limiting step for decolourization (Chang et al., 2001a; Kodam et al., 2005). This $\mathrm{pH}$ tolerance of decolourizing bacteria is quite important, as it makes them suitable for practical bio-treatment of dyeing mill effluents (Aksu and Donmez, 2003; Wang et al., 2009).

\subsection{Effect of Temperature on Decolourization of RB19}

In microorganisms the environmental temperature directly establishes organismal temperature, as the microbial cell responds to temperature changes by adaptation via biochemical or enzymatic mechanisms. Consequently, temperature is a factor of paramount importance for all processes associated with microbial vitality, including the remediation of water and soil. The dye decolourization activity of our culture was found to increase with increase in incubation temperature from 20 to $27^{\circ} \mathrm{C}$ with maximum activity attained at $27^{\circ} \mathrm{C}$ (92.34\% de colourization) Fig. 4. Further increase in temperature resulted in marginal reduction in decolourization activity of culture $B$. cereus. it has also been reported that in microbial physiology temperature changes lead to a sudden alteration of the activation energy (Yu et al., 2001). Moreover, the effects of temperature on the growth rate, biomass yield and reaction mechanism have also been reported (Blaga et al., 2008).

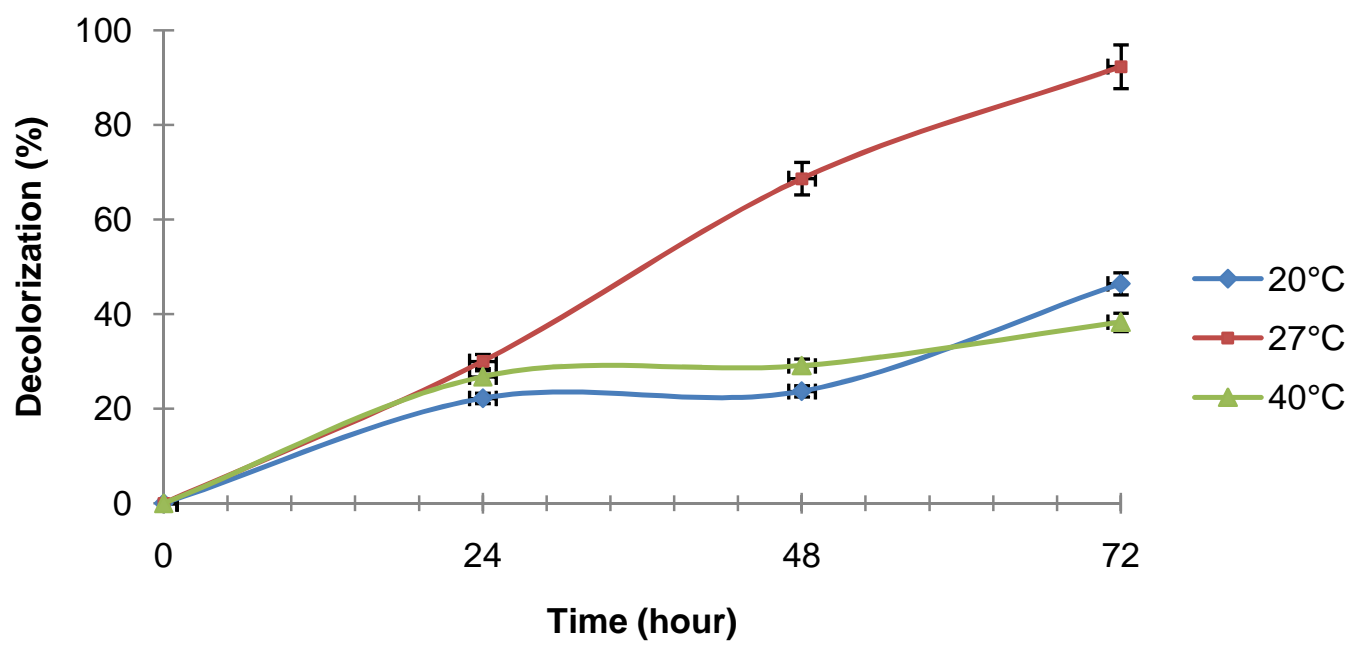

Fig. 4. The Effect of Temperature on Decolourization of RB19, and each data point is the average of triplicates and the error bars represent $95 \%$ confidence interval

\section{CONCLUSION}

The present study confirms the ability of $B$. cereus to decolourize the Reactive blue 19 with a decolourization efficiency of $95 \%$. The presence of a co-substrate (glucose) is an essential condition for attaining maximum decolourization efficiency. The results thus obtained have characterized and identified the dye degrading ability of the Bacillus. The Bacillus strain has the ability to tolerate, decolourize and degrade azo dyes even at high concentration. Reactive blue 19 was completely and rapidly decolourized by Bacillus after 3days of incubation with different effects on the dye as seen in the result. 


\section{COMPETING INTERESTS}

Authors have declared that no competing interests exist.

\section{REFERENCES}

Aksu, Z., Donmez, G. (2003). A comparative study on the biosorption characteristics of some yeast for remazol blue reactive dye. Chemosphere, 50, 1075.

Banat, I.M., Nigam, P., Singh, D., Marchant, R. (1996). Microbial decolourization of textile dye-containing effluents: a review. Bioresour. Technol., 58, 217-227.

Blaga, A., Tatyana, A., Lilyana, S., Sava, M. (2008). Temperature effect on bacterial azo bond reduction kinetics: an arrhenius plot analysis. Biodegradation, 19, 387.

Chang, J.S., Chou, C., Lin, Y., Ho, J., Hu, T.L. (2001). Kinetic characteristics of bacterial Azo-Dye decolourization by Pseudomonas luteola. Water Res., 35, 2041.

Forgacs, E., Cserhati, T., Oros, G. (2004). Removal of synthetic dyes from wastewaters: a review. Environ. Int., 30, 953-971.

Giwa, A., Akpan, U.G., Nkeonye, P.O., Bello, K.A., Kolawole, E.G. (2011). Solar photocatalytic degradation of acid blue 29. Journal of the Chemical Society of Nigeria, $36,82-89$.

Hadibarata, T., Yusoff, A.M., Kristanti, R.A. (2012a). Decolorization and Metabolism of anthraquionone-type dye by laccase of white-rot fungi Polyporus sp. S133. Water Air Soil Pollut, 223, 933-941. DOI 10.1007/s11270-011-0914-6.

Hadibarata, T., Yusoff, A.M., Aris, A., Salmiati, Hidayat, T., Kristanti, R.A. (2012b). Decolorization of Azo, triphenylmethane and anthraquinone dyes by laccase of a newly isolated Armillaria sp. F022. Water Air Soil Pollut (2012), 223, 1045-1054. DOI 10.1007/s11270-011-0922-6.

Jadhav, S.U., Jadhav, M.U. Kagalkar, A.N., Govindwar, S.P. (2008). Decolourization of brilliant blue $G$ Dye mediated by degradation of the microbial consortium of Galactomyces geotrichum and Bacillus sp. J. Chin. Inst. Chem. Engrs., 39, 563.

Kalyani, D.C., Telke, A.A., Dhanve, R.S., Jadhav, J.P. (2008). Ecofriendly biodegradation and detoxification of reactive red 2 textile dye by newly isolated pseudomonas sp. SUK1. J. Hazard. Mater, 163, 735.

Kodam, K.M., Soojhawon, I., Lokhande, P.D., Gawai, K.R. (2005). Microbial decolourization of reactive azo dyes under aerobic conditions. World J. Microbiol. Biotechnol., 21, 367.

Liu, W., Chao, Y., Yang, X., Bao, H., Qian, S., (2004). Biodecolourization of azo, anthraquinonic and triphenylmethane dyes by white-rot fungi and a laccasesecreting engineered strain. Journal of Industrial Microbiology \& Biotechnology, 31, 127-132.

Ohmomo, S., Daengsubha, W., Yoshikawa, H., Yui, M., Nozaki, K., Nakajima, T., Nakamura, I. (1988). Screening of anaerobic bacteria with the ability to decolourize molasses melanoidin. Agric. Biol. Chem., 57, 2429-2435.

Padamavathy, S., Sandhya, S., Swaminathan, K., Subrahmanyam, Y.V., Kaul, S.N. (2003). Comparison of decolourization of reactive azo dyes by microorganisms isolated from various source. Journal of Environmental Sciences, 15, 628-632.

Pandey, A., Singh, P., lyengar, L. (2007). Bacterial decolourization and degradation of azo dyes. Int. Biodeter. Biodegr., 59, 73-84.

Pearce, C.I., Lloyd, J.R., Guthrie, J.T. (2003). The removal of colour from textile wastewater using whole bacterial cells: a review. Dyes and Pigments, 58, 179-196. 
Rhodehamel, E.J., Harmon, S.M. (2001). FDA bacteriological analytical manual, $8^{\text {th }}$ Ed, revision a, us food and drug administration, center for food safety and applied nutrition, College Park, MD, Chapter 14.

Saranaik, S., Kanekar, P. (1995). Bioremediation of colour of methyl violet and phenol from a dye industry waste effluent using Pseudomonas sp. isolated from factory soil. J. Appl. Bacteriol., 79, 459-469.

Saratale, R.G., Saratale, G.D., Chang, J.S., Govindwar, S.P. (2009a). Ecofriendly decolourization and degradation of reactive green 19A using Micrococcus glutamicus NCIM-2168. Bioresour. Technol., 110, 3897.

Saratale, R.G., Saratale, G.D., Kalyani, D.C., Chang, J.S., Govindwar, S.P. (2009b). Enhanced decolourization and biodegradation of textile azo dye scarlet $\mathrm{R}$ by using developed microbial consortium-GR. Bioresour. Technol., 100, 2493.

Spadaro, J.T., Gold, M.H., Renganathan, V. (1992). Degradation of azo dyes by the lignin degrading fungus Phanerochaete chrysosporium. Appl. Environ. Microbiol, 58, 23972401.

Verma, P., Madamwar, D. (2003). Decolourization of synthetic dyes by a newly isolated strain of Serratia marcescens. World Journal of Microbiology and Biotechnology 19, 615-618.

Wang, R.C., Fan, K.S., Chang, J.S. (2009). Removal of acid dye by $\mathrm{ZnFe}_{2} \mathrm{O}_{4} / \mathrm{TiO}_{2^{-}}$ immobilized granular activated carbon under visible light irradiation in a recycle liquidsolid fluidized bed. J. Taiwan Inst. Chem. Engrs., 40, 533.

Watanabe, Y., Sugi, R., Tanaka, Y., Hayashida, S. (1982). Enzyamatic of melanoidin by Coriolus sp. No.20. Agric. Biol. Chem., 46, 1623-1630.

Yu, J., Wang, X., Yue, P. (2001). Optimal decolourization and kinetic modeling of synthetic dyes by Pseudomonas strains. Water Res., 35, 3579.

(C) 2012 Giwa et al.; This is an Open Access article distributed under the terms of the Creative Commons Attribution License (http://creativecommons.org/licenses/by/3.0), which permits unrestricted use, distribution, and reproduction in any medium, provided the original work is properly cited. 